\title{
Internalisasi Nilai-Nilai Islam Dalam Membentuk Sikap Sosial Siswa Melalui Pembelajaran Akidah Akhlak Kelas VA Di MI Bustanul Ulum Pesanggrahan Batu
}

\author{
${ }^{1}$ Marudin, ${ }^{2}$ Munawir Gozali \\ ${ }^{1}$ Institut Agama Islam Hamzanwadi NW Pancor \\ ${ }^{2}$ Institut Pendidikan Nusantara Global, Lombok Tengah \\ ${ }^{1}$ Email: markmarudin88@gmail.com
}

\begin{abstract}
Abstrak
Sikap sosial merupakan tujuan pendidikan nasional dan menjadikan karakter bangsa yang berpradaban. Pelajaran akidah akhlak menjadi salah satu pendidikan wajib untuk membentuk sikap sosial siswa melalui internalisasi nilai ilahiyah dan insaniyah. Untuk mewujudkan sikap sosial diperlukannya desain internalisasi nilai-nilai Islam yang terdapat dalam pembelajaran akidah akhlak.

Penelitian ini bertujuan untuk menganalisis dan mendeskripsikan sikap social siswa di MI Bustanul Ulum Pesanggrahan Batu yang dilakukan pada (1) Bagaimana desain internalisasi nilai-nilai Islam melalui pembelajaran akidah akhlak (2) Bagaimana implementasi desain pembelajaran akidah akhlak dalam membentuk sikap sosial siswa (3) Bagaimana hasil implementasi internalisasi nilai-nilai Islam dalam membentuk sikap sosial siswa melalui pembelajaran akidah akhlak. Pendekatan penelitian menggunakan kualitatif diskriptif. Subjek penelitian yaitu kepala sekolah, waka kurikulum, guru akidah akhlak. Teknik pengumpulan data menggunakan wawancara, observasi, dan dokumentasi. Analisis data menggunakan reduksi data, penayjian data dan kesimpulan.

Hasil penelitian Pertama menggunakan desain secara makro melalui kerja sama dengan semua komponen yang ada di sekolah, dukungan orang tua dan masyarakat, mikro yaitu melalui proses pembelajaran dalam kelas dan luar kelas, dengan melakukan tahapan perencanaan, transfer pengetahuan, keteladanan, pembiasaan, trainternalisasi dan evaluasi. Kedua implementasi desain dengan cara (1) membuat RPP yang mengacu pada Kopetensi inti dan Kompetensi dasar berpedoman pada Kurikulum 2013 (2) transfer pengetahuan dengan nilai ilahiyah dan nilai insaniyah mencakup pada nilai keimanan, ketakwaan, kejujuran, kedisiplinan, amanah, tanggung jawab, tolong menolong, peduli kebersihan (3) keteladanan di dalam kelas dan luar kelas .(4) pembiasaan dengan kegiatan keagamaan di sekolah dan dalam KBM dengan menggunakan metode pembelajaran (5) trainternalisasi dengan pengawasn, memberikan nasehat, teguran dan sanksi (6) evaluasi dengan ulangan harian, UTS, UAS. Ketiga hasil implementasi internalisasi dapat dilihat dengan terciptanya keadaan kelas dan sekolah yang riligius, siswa yang disiplin, jujur, bertanggung jawab.
\end{abstract}

Kata kunci : Internalisasi, nilai-nilai Islam, sikap sosial 


\section{PENDAHULUAN}

Kehidupan dalam suatu negara, sudah pasti pendidikan masih memegang peran yang sangat penting untuk menjamin kelansungan hidup dalam suatu bangsa dan negara, karena pendidikan merupakan upaya untuk meningkatkan dan mengembangkan kualitas sumberdaya manusia. Pendidikan merupakan usaha untuk menyiapkan siswa supaya dapat berperan aktif dan positif dalam hidupnya baik sekarang maupun masa yang akan datang.

Undang-undang RI Nomer 20 Tahun 2003 tentang sistem pendidikan Nasional pasai 1 ayat (1) disebutkan bahwa pendidikan merupakan usaha sadar dan terencana untuk dapat mewujudkan suasana belajar dan proses pembelajaran agar peserta didik secara aktif mengembangkan potensi dirinya untuk memiliki kekuatan spiritual keagamaan, pengendalian diri, kepribadian, akhlak mulia, serta keterampilan yang diperlukan dirinya, masyarakan, bangsa dan negara. ${ }^{1}$

Berdasarkan pengertian dan fungsi pendidikan yang telah di sebutkan di atas, maka dapat di simpulkan bahwa pendidikan mencakup aspek pengetahuan, sikap, dan keterampilan. Hal ini selaras dengan pendapat Bloom yang menyatakan bahwa bentuk perilaku yang harus dirumuskan dalam tujuan pendidikan dapat digolongkan ke dalam tiga klasifikasi atau tiga bidang, yaitu bidang kognitif, afektif dan pisikomotorik. $^{2}$ Bidang kognitif untuk tujuan pendidikan yang berhubungan dengan kemampuan intlektual, domain afektif berkenaan dengan sikap, nilai-nilai dan apresiasi, serta domain pisikomotorik yang meliputi semua tingkah laku yang menggunakan syaraf dan otot badan.

Terjadinya fakta tersebut merupakan contoh kecil dari indikasi terjadinya kerusakan sikap berbangsa dan bernegara sebagai generasi muda penerus bangsa dan pelajar yang seharusnya menjadi generasi

\footnotetext{
${ }^{1}$ Undang-undang RI Nomer 20 Tahun 2003 Tentang SISDIKNAS, Penyelenggaraan Pendidikan dan Wajib Belajar (Bandung: Citra Umbara, 2012), hlm. 2

${ }^{2}$ Wina Sanjaya, Prencanaan Dan Desain Sistem Pembelajaran (Jakarta: Kencana, 2008). 125
} 
penerus yang cerdas, berprestasi, berakhlak mulia, beriman pada Tuhan Yang Maha Esa. Maka dalam proses pembelajaran di sekolah sangat penting untuk menanamkan sikap yang baik kepada anak didik sehingga bisa menjadi generasi bangsa yang mengedepankan sikap yang baik dan toleransi terhadap perbedaan yang ada .

Peran guru dalam proses belajar mengajar tidak hanya sebagai pengajar lagi seperti yang menonjol selama ini, melainkan juga sebagai pelatih, pembimbing, dan pengatur pembelajaran siswa, hal ini sesuai dengan peran guru masa depan. Guru sebagai pelatih akan berperan mendorong siswa untuk menguasai alat belajar, memotivasi siswa untuk bekerja keras, mencapai prestasi tinggi dan memiliki sikap yang baik. Peranan guru dalam proses pembelajaran belum dapat digantikan oleh mesin, radio, atau computer yang paling modern sekalipun. Masih terlalu banyak unsur-unsur manusiawi seperti sikap, sistem, nilai, perasaan, motivasi, kebiasaan dan lain-lain yang diharapkan dari hasil proses pembelajaran, semua itu tidak dapat dicapat melalui alat-alat tersebut. Guru mempunyai kelebihan dari alat-alat atau teknologi yang diciptakan manusia untuk membantu dan mempermudah kehidupannya.

Sikap sosial menjadi suatu hal yang penting dalam kehidupan bersama pada suatu masyarakat, mengingat kita hidup di tengah-tengah masyarakat Indonesia yang beragam dan tentu saja selama kehidupannya manusia tidak akan pernah terlepas dengan adanya suatu interaksi dengan manusia lain. Karena dengan adanya interaksi sosial yang baik diharapkan akan menimbulkan perasaan sosial yang dapat mengikatkan individu dengan sesama manusia dalam bentuk tolong menolong saling menghormati dan menerima.Sikap sosial merupakan kesadaran dalam diri individu terhadap lingkungan sosial di sekitarnya. Sikap sosial biasanya ditunjukkan karena adanya rasa perhatian dan kepedulian terhadap lingkungan dimana seorang tersebut berbeda. Sedangkan sikap sosial dasar 


\section{BADA'A: Jurnal Ilmiah Pendidikan Dasar}

Vol. 1, No. 2, Desember 2019, Hal. 97-107

E-ISSN:

2714-7711

merupakan hal-hal atau sikap yang mendasari perkembangan sosial setiap individu. $^{3}$

Akhir-akhir ini sering kita melihat di media sosial, media masa baik itu di TV, Koran dan lain-lain, betapa banyak-nya siswa sekolah dasar yang melakukan perbuatan yang tidak baikuntuk dilakukan, seperti berkelahi dengan teman sampai ada yang meninggal dunia, ${ }^{4}$ bullying, mencuri, suka berbohong, tidak disiplin, tidak tanggung jawab, tidak sopan santun, tidak menghargai guru, tidak menghargai teman, tidak amanah dan lain-lain.Dengan adanya fakta tersebut sangat memperhatinkan kondisi generasi bangsa untuk masa yang akan datang.

Pendidikan dasar merupakan dimana pase berpikir konkrit, karena pada usia 7-12 tahun mereka mulai dapat menghayati dan berpikir secara logis peristiwa-peristiwa yang konkrit, ${ }^{5}$ artinya pada usia sekolah dasar ini peserta didik sudah biasa mulai di ajak berpikir mengenai hal-hal yang konkrit akan tetapi dengan menggunakan cara-cara yang sesuai dengan usia siswa seperti bermain, belajar dalam kelompok dan lain sebagainya.Usia sekolah dasar masih merupakan pase pembentukan , artinya anak dengan mudah memasukkan asupan pengalaman dan pelajaran yang dia lihat dan yang didengar.

Dalam proses pembentukan sikap sosial siswa di sekolah tidak bisa lepas dari nilai-nilai Islam, karena dalam sikap sosial sudah menjadi satu kesatuan dalam nilai-nilai Islam. Oleh karena itu guru perlu hati-hati dalam memberikan asupan pelajaran dan pengetahuan kepada peserta didiknya, sehingga nilai-nilai yang di internalisasikan kepada anak harus berupa nilai-nilai yang luhur dan sesuai dengan nilai-nilai Islam yang ada. hlm. 61 .

${ }^{3}$ Azwar, Sikap Manusia Teori Dan Pengukurannya, (Yogyakarta: Pustaka Belajar, 2012),

${ }^{4}$ Siswadi Garut Meninggal Dunia Karena Berkelahi Dengan Teman Kelasnya, Net NEWS, 24 Juli 2018.

${ }^{5}$ Desmita, Pisikologi Perkembangan Peserta Didik; Panduan Bagi Orang Tua Dan Guru Dalam Memahami Pisikologi Anak Usia Sd-Sma (Bandung: PT Remaja Rosdakarya, 2014),hlm. 15 
Pendidikan nilai merupakan upaya untuk membantu peserta didik mengenal, memahami pentingnya menginternalisasikan nilai-nilai yang pantas dan semestinya dijadikan panduan bagi sikap dan perilaku manusia baik secara prorangan maupun secara kelompok dalam suatu masyarakat. Nilai mendasari prinsip dan norma yang memandu sikap dan prilaku orang dalam hidup. Kualitas seseorang ditentukan oleh nilai-nilai yang senyatanya dihayati sebagai pemandu sikap dan perilakunya, baik dalam hubungannya dengan diri sendiri, alam sekitar maupun dengan tuhan.

Nilai-nilaiIslam adalah bagian dari nilai material yang terwujud dalam kenyataan rohani dan jasmani. Nilai-nilaiIslam merupakan tingkatan integritas kepribadian yang mencapai tingkat budi (insan kamil). Niali-nilai Islam bersifat mutlak kebenarannya, universal dan suci. Kebenaran dan kebaikan agama mengatasi rasio, perasaan, keinginan, nafsu-nafsu manusiawi dan mampu melampui subjektifitas ras, bangsa dan stratifikasi sosial. $^{6}$

Internalisasi adalah penghayatan, pendalaman, penguasaan dan serta mendalam melalui binaan, bimbingan dan sebagainya. Dengan demikian internalisasi merupakan suatu proses penanaman sikap dan sebagainya agar ego menguasai secara mendalam suatu nilai dan serta menghayati sehingga dapat tercermin dalam sikap tingkah laku sesuai dengan standar yang diharapkan. Sedangkan internalisasi yang dihubungkan denganIslam dapat diartikan sebagai proses memasukkan nilai-nilaiIslam secara utuh kedalam hati, sehingga ruh dan jiwa bergerak berdasarkan ajaran Islam. Internalisasi nilaiIslam terjadi melalui pemahaman ajaran agama Islam secara utuh dan didasarkan dengan kesadaran akan pentingnya Islam, serta ditemukannya posibilitas untuk merealisasikannya dalam kehidupan nyata.

${ }^{6}$ Departemen Pendidikan dan Kebudayaan, Kamus Besar Bahasa Indonesia (Jakarta: Balai Pustaka, 1989), hlm. 22 


\section{METODE PENELITIAN}

Tujuan yang ingin diangkat oleh peneliti dalam penelitan ini untuk mengetahui nilai-nilaiIslam apa saja yang diinternalisasikan melalui mata pelajaran akidah akhlak untuk membentuk sikap sosial siswa di MI Bustanul Ulum Pesanggrahan kota Batu. Untuk mencapai tujuan tersebut, maka peneliti menggunakan metode kualitatif dengan pendekatan diskriptif. Data-data yang akan diperoleh melalui kata-kata tertulis atau lisan dan prilaku yang dapat diamati melalui wawancara, observasi dan dokumentasi.

Menurut Bogdan dan Taylor yang dikutip oleh Andi Pastowo, bahawasanya metodologi kualitatif adalah prosedur penelitian yang menghasilkan data diskriptif kualitatif berupa kata-kata tertulis atau lisan dari orang-orang dan perilaku yang diamati. Menurut keduanya, pendekatan ini diarahkan pada latar dan individu secara menyeluruh (holistic). Ini berarti bahwa individu tidak boleh diisolasi atau diorganisasikan ke variabel atau hipotesis, namun perlu dipandang sebagai bagian dari suatu keutuhan. ${ }^{7}$

\section{HASIL PENELITIAN DAN PEMBAHASAN}

Desain internalisasi nilai-nilai Islam melalui pembelajaran akidah kahlak di MI Bustanul Ulum Pesanggrahan

Dalam mengupayakan internalisasi nilai-nilai Islam dalam membentuk sikap sosial siswa melalui pembelajaran akidah akhlak di kelas dilakukan dengan dua acara yaitu secara mikro dan makro, secara mikro dengan memaksimalkan kegiatan belajar mengajar di kelas maupun di luar kelas, di kelas meliputi perencanaan dalam membuat rencana pelaksanaan pembelajaran (RPP), transfer pengetahuan, memberikan keteladanan, melakukan pembiasaan, melakukan trainternalisasi, dan melakukan evaluasi. Internalisasi nilai-nilai Islam melibatkan semua

\footnotetext{
${ }^{7}$ Andi Prastowo, Metode Penelitian Kualitatif Dalam Prespektif Rancangan Penelitian, (Jogjakarta: Ar-Ruzz Media, 2011), hlm. 22
} 
peserta didik secara aktif dalam pembelajaran dengan meningkatkan komunikasi dan kerjasama dalam belajar, meningkatkan keberanian peserta didik dalam mengambil resiko, belajar dari kesalahan, meningkatkan pembelajaran sambil melakukan.

Desain internalisasi nilai-nilai Islam melalui pembelajaran akidah akhlak di MI Bustanul Ulum Pesanggrahan Batu di kelompokkan menjadi 5 tahap yaitu perencanaan, transfer pengetahuan, keteladanan, pembiasaan, trainternalisasi, dan evaluasi. Pada tahap perencanaan yang di gali dan dirumuskan dengan berbagai sumber idiologi bangsa, perundangan yang terkait pisikologis, nilai moral, sosiokultural serta pertimbangan empiris berupa pengalaman dan praktik terbaik dari tokoh-tokoh. Tahap transfer pengetahuan merupakan tapah memberikan pemahaman tentang nilai-nilai Islam baik nilai ilahiyah maupun nilai insaniyah agar siswa bisa menghayati apa yang di harus dilakukan dan apa yang dilarang dalam ajaran agama Islam.

\section{Implementasi desain pembelajaran akidah akhlak dalam membentuk sikap sosial siswa di MI Bustanul ulum Pesanggrahan}

Implementasi desain pembelajaran akidah akhlak dalam membentuk sikap sosial siswa di MI Bustanul Ulum Pesanggrahan Batu selain dari proses pembelajaran di dalam kelas juga melalui programprogram keagamaan yang ada di sekolah. Program keagamaan ini dimasukkan ke dalam kegiatan ekstrakuikuler keagamaan sebagai wadah agar bisa terkontrol dengan baik dalam pelaksanaan internalisasi nilai-nilai Islam, seperti membaca Al-Qur'an, sholat dhuha, sholat dzuhur berjamaah, istighosah dan baca yasin bersama dan diluar kegiatan keagamaan terapkan siswa harus disiplin datang ke sekolah, disiplin dalam berpakaian, disiplin dalam mengikuti kegiatan-kegiatan di sekolah, dilatih 
menjadi siswa yang bertanggung jawab baik dalam perbuatan maupun ucapan, dilatih selalu mengucapkan salam apabila bertemu dengan guru dan teman-temannya dan kegiatan jum'at bersih yang terus menerus dilakukan.

\section{Hasil implementasi internalisasi nilai-nilai Islam dalam membentuk sikap sosial siswa melalui pembelajaran akidah akhlak di MI Bustanul Ulum Pesanggrahan}

Hasil internalisasi nilai-nilai Islam dalam membentuk sikap sosial siswa melalui pembelajaran akidah akhlak yaitu: Prestasi baik secara akademik maupun non akademik semakin meningkat, Peserta didik mumpunyai akhlak yang mulia sehingga lebih disiplin, bertanggung jawab, jujur, percaya diri, menghormati guru, saling menghargai, saling menolong, amanah, peduli kebersihan di dalam kelas dan lingkungan sekolah, lulusan dari lembaga tersebut mampu di terima di sekolahsekolah negri, kepercanyaan masyarakat terhadap lembaga semakin tinggi dengan terus bertambahnya siswa setiap tahunnya, tingkat kepribadian dalam menjalankan nilai-nilai Islam, dalam bersosial siswa dan percaya diri siswa semakin membaik, tingkat kecerdasan tidak hanya intlektual saja tapi juga kecerdasan spiritual, kecerdasan emosional, dan kecerdasan sosial terus membaik.

Hasil internalisasi nilai-nilai Islam dalam membentuk sikap sosial siswa melalui pembelajaran akidah akhlak, siswa yang memahami nilainilai Islam dan mempunyai sikap sosial yang baik maka akan meningkatkan prestassi baik secara akademik maupun non akademik, dalam penelitian Josep Zins dalam bukunya Zubaedi ada factor resiko penyebab kegagalan anak di sekolah teryata bukan terletak pada kecerdasan otak, tetapi pada karakter yaitu rasa percaya diri, kemampuan 


\section{BADA'A: Jurnal Ilmiah Pendidikan Dasar}

Vol. 1, No. 2, Desember 2019, Hal. 97-107

E-ISSN:

2714-7711

bekerjasama, kemampuan bersosial, rasa empati dan kemampuan berkomunikasi. ${ }^{8}$

Sesuai dengan penelitiannya Daniel Golman tentang keberhasilan seseorang di masyarakat 80 persen dipengaruhi kecerdasan emosi dan 20 persen dipengaruhi kecerdasan otak. Anak-anak yang mempunyai masalah dalam kecerdasan emosinya, akan mengalami kesulitan belajar, bergaul dan tidak dapat mengontrol emosinya. Anak-anak yang bermasalah ini sudah dapat dilihat sejak usia pra-sekolah dalam berprilaku, bersikap, maka tindakan ini kalu tidak segera diatasi maka akan terbawa sampai usia dewasa. Sebaliknya para remaja yang mempunyai sikap sosial yang baik dan kecerdasan emosi tinggi akan terhindar dari masalah-masalah umum yang di hadapi oleh anak-anak dan remaja seperti berkelahi dengan teman, tidak menghargai guru, orang tua dan teman baik di sekolah maupun luar sekolah, melanggar aturan-aturan yang ada di sekolah, meremehkan tanggung jawab yang diberikan.

\section{KESIMPULAN}

Berdasarkan data, pembahasan dan temuan penelitian ini dapat disimpulkan sebagai berikut:Desain internalisasi nilai-nilai Islam melalui pembelajaran Akidah Akhlak menggunakan desain makro dan mikro. secara makro melalui kerja sama dengan semua komponen yang ada di sekolah, dukungan orang tua dan dan masyarakat..Secara mikro yaitu melalui proses pembelajaran dalam kelas dan luar kelas, melalui kegiatan keagamaan dan kegiatan ekstrakurikuler di sekolah.

Implementasi desain pembelajaran Akidah Akhlak dalam membentuk sikap sosial siswa dengan cara mengimplementasikan desain

\footnotetext{
${ }^{8}$ Zubaedi, Desain Pendidikan Karakter, Konsepsi Dan Aplikasinya, Dalam Lembaga Pendidikan (Jakarta: Media Group, 2011), hlm. 39.
} 


\section{BADA'A: Jurnal Ilmiah Pendidikan Dasar}

Vol. 1, No. 2, Desember 2019, Hal. 97-107

E-ISSN:

2714-7711

yang sudah di buat trainternalisasi dilakukan dengan pengawasn, memberikan nasehat, teguran dan memberikan sanksi f) evaluasi dengan melakukan ulangan harian (UH), ulangan tengah semester (UTS), ulangan akhir semester (UAS).Hasil implementasi internalisasi nilai-nilai Islam dalam membentuk sikap sosial siswa melalui pembelajaran akidah akhlak dapat melahirkan a) keadaan kelas dan sekolah yang riligius dan siswa lebih berakhlak mulia, lebih disiplin,jujur, bertanggung jawab, amanah, percaya diri, saling menghargai, tolong menolong peduli kebersihan dan keindahan. b) Prestasi siswa dapat berhasil baik secara akademik maupun non akademik dan, c) kepercayaan masyarakat terhadap lembaga semakin tinggi. 


\section{DAFTAR PUSTAKA}

Ayu Dewi Ida dkk, Deskripsi Sikap Sosial Pada Siswa Kelass IV SD Negeri 4 Penarukan Kecamatan Buleleng Kabupaten Buleleng, e-jurnal PGSD Universitas Pendidikan Ganesa Jurusan PGSD Vol: 4 No. 1 Tahun 2016.

Asmawati asmawati, Riyadi, Imam Sujadi, Proses Integrase Sikap Sosial Dan Spiritual Dalam Pembelajaran Matematika Pada Siswa Kelas VII SMP Negeri Di Kecamatan Purwadadi, Jurnal Elektronik Pembelajaran Matematika, Vol, 4, No.1. Maret 2016.

Ali Mukti, Kehidupan Beragam Dalam Proses Pembangunan BangsaBandung: Proyek Pembinaan Mental Agama, 1975.

Azwar, Sikap Manusia Teori Dan Pengukurannya, Yogyakarta: Pustaka Belajar, 2012.

Ahmad Abu, Pisikologi Sosial Jakarta: Rineka Cipta, 2007.

Alim M, Pendidikan Agama Islam Upaya Pembentukan Pikiran Dan Kepribadian MuslimBandung: Remaja Rosdakarya, 2006.

Aly Nur Hery Dan Munzir, Watak Pendidikan IslamRiska Agung Insani, 2000.

Agustian Ginanjar Ary, ESQ Emational, Spiritual, Quotient, Jakarta: Arga, 2005.

Armai Arif, Pengantar Ilmu Dan Metodologi Pendidikan Islam Jakarta: Ciputat Pers, cetakan ke, 2002.

B. Uno Hamzah, Teori Motivasi Dan Pengukurannya Jakarta: PT Bumi Aksara, 2011. 